\title{
Nyílt forráskódú szoftverek a gazdaságban és az e-kormányzatban
}

\section{Szerzői információ:}

Rab Árpád Szörény

Antropológus-etnográfus, az Információs Társadalom- és Trendkutató Központ (ITTK) vezetố kutatója és projektkoordinátora. Fố kutatási területe a digitális kultúra, kiemelten a kulturális örökség digitalizálása, az információs írástudás témaköre, a virtuális világok és az úgynevezett „komoly játékok” (serious games). Jelenleg két doktori disszertáción dolgozik a fenti témakörökben.

Így hivatkozzon erre a cikkre:

Rab Árpád. „Nyílt forráskódú szoftverek a gazdaságban és az e-kormányzatban”. Információs Társadalom VIII, 3. szám (2008): 157-162.

- https://dx.doi.org/10.22503/inftars.VIII.2008.3.12

A folyóiratban közölt müvek

a Creative Commons Nevezd meg! - Ne add el! - Így add tovább! 4.0

Nemzetközi Licenc feltételeinek megfelelöen használhatók. 
Rab Árpád

\title{
Nyílt forráskódú szoftverek
}

\author{
a gazdaságban \\ és az e-kormányzatban
}

A nyílt forráskódú szoftverek néhány évvel ezelốtt egy önkéntes fejlesztôi mozgalomból kiindulva kezdtek tömegesen elterjedni, és mára a világ szoftverpiacának, IK'T-gazdaságának és e-kormányzati törekvéseinek kikerülhetetlen szereplói. A nyílt forráskódú szoftverekben rejlő lehetôségek mind Magyarországon, mind pedig az Európai Unióban egyelốre még jórészt kihasználatlanok. Az alábbiakban ezekról a lehetôségekról és egy-két jó példáról számolunk be.

A nyílt forráskódú szoftverek térhódítása mára megfellebbezhetetlen tény, ezt mind a gazdasággal, mind az információs társadalommal kapcsolatos felmérések, elemzések igazolják. Az Európai Unióban az információs társadalom zászlóshajói közé tartoznak, 2000 óta ajánlások és projektek, befektetett eurómilliók mutatják kiemelt fontosságukat. Az Európai Bizottság 2008 márciusában megjelent ajánlása a jövôre nézve minden uniós forrásokból finanszírozott fejlesztési program számára a nyílt, jól dokumentált szabványok elốnyben részesítését jelöli meg kizárólagos követendő irányként.

Nagyon fontos leszögezni, hogy a nyílt forráskódú szoftverekben nem valamiféle ingyenes, ellenôrizetlen és ellenórizhetetlen félmegoldások, hanem kiforrott üzleti modellek testesülnek meg. Nem ingyenesek, hanem olcsóbbak, szabadabbak és interoperábilisak, vagyis alapvetố kormányzati és gazdasági elvárásoknak tesznek eleget. A nyílt forráskódú szoftverek kezdetben leginkább a „dobozos” szoftverek ellenpéldájaként, biznyos szabadságharcos-ellenállási lehetôségként jelentek meg. Bár a szabad szoftverek, illetve „dobozos” kereskedelmi megoldások elsóbbségéról folyó vitára még ma is az érzelmi túlfútöttség jellemzô, a piaci és a kormányzati szereplók számára már egy ideje világos, hogy itt nem érzelmekrôl, hanem üzletról és lehetőségekról van szó.

Az utóbbi évtizedben a nyílt forráskódú szoftverek bizonyíthatták is minôségi fölényüket. Rengeteg külföldi példa mutatja (a szomszédos országokból is), hogy ezek a szoftverek kimagaslóan jól alkalmazhatók a következő területeken a jelzett eredményekkel:

- e-kormányzat (a költségek jelentôs csökkentése, az immár alapfeltételnek számító interoperabilitás, az állampolgári jogok biztosítása);

- oktatás (szinte határtalan lehetőségek, költségcsökkentés, versenyképes oktatás, interoperábilis megoldások);

- gazdaság (a piacok élénkítése - a legutóbbi francia gazdasági stratégiákban ez a funkciójuk már fontos szerepet játszik, a GDP kimutatható növekedését várják tôle);

- mindennapi élet (a legális szoftverhasználat terjedése, a belföldi piacok erősödése). 


\section{A nyílt forráskódú szoftverek előnyei}

A nyílt forráskódú szoftverek legfontosabb sajátossága, hogy forráskódjuk megszerezhetô. Ez azt jelenti, hogy ezeket a programokat a felhasználó - függetlenül a program készítôitól - többnyire tetszése szerint megváltoztathatja és bárkinek továbbadhatja, továbbá a felismert hibákat vagy gyenge pontokat nyilvánosságra hozhatja. Ezek a programok éppen azért kapták a nyílt forráskódú szoftver (Open Source Software, OSS) nevet, mert a forráskódjukhoz bárki hozzájuthat. Megjelölésükre a szabad szoftver kifejezés is használatos, ami szintén a felhasználó szabadságára utal. Ezzel szemben a védett szellemi tulajdonként értékesített (proprietary) szoftvereket a felhasználó nem vizsgálhatja meg, és nem változtathat rajtuk. Forráskódjukat legális úton nem olvashatja el és nem értheti meg. Mit jelent ez a gyakorlatban? A nyílt forráskódú szoftverek ugyanúgy pénzbe kerülnek, kidolgozásukhoz ugyanúgy szükség van professzionális programozókra, támogatásra, kézikönyvekre stb., viszont

- az így elkészült szoftverek forráskódját át kell adni (a termék a vásárlóhoz kerül, aki késóbb azt módosíthatja, partnert cserélhet stb., nincs „,bezárva” az adott fejlesztốcéggel való kapcsolatába);

- az elkészült szoftver interoperábilis: tud más hasonló szoftverekkel kommunikálni, vagy továbbfejleszthetố ilyen irányban (az e-kormányzati szolgáltatásoknál például alapvetốen fontos a hivatalok közötti kommunikáció, sốt ezen a téren az Európai Unióban már az országok közötti kommunikáció jelenti a legújabb kihívást);

- ezekért a szoftverekért nem kell licencdíjat fizetni, a kifejlesztett szoftvert akárhányan letölthetik, felhasználhatják. (A licencdíjak már városi önkormányzati szinten is hatalmas összegek, országos szinten pedig már jelentôs költségvetési terhet jelentenek.)

A fentiekhez még hozzá kell tennünk, hogy ezek a szoftverek legálisak, és az IKT-szakemberek rámutatnak felhasználásuk magasabb biztonsági szintjére is.

A fenti elónyöket végiggondolva belátható, hogy a nyílt forráskódú vagy szabad szoftverek alkalmazásával mind az e-kormányzat, mind pedig az e-gazdaság piaci szegmensében többféle szinten is jelentkezó pozitív hatásokat lehet elérni. Ez a felismerés vezette az Európai Uniót és a világ számos nagy nemzetét (az Egyesült Államokat, Oroszországot, Japánt, Kínát stb.) arra, hogy az OSS felhasználását kiemelt fontosságú kérdésként kezeljék. A várakozások beváltak, ezt bizonyítja az elmúlt öt év számos projektje.

\section{Jó megoldások, jellemző példák}

A nyílt forráskódú szoftverek megbízhatósága bizonyított tény. Az Európai Unió úrkutatási programjától kezdve a kutatás-fejlesztés számos más fontos területéig találkozhatunk velük; ezek a programok számtalan pénzügyi szolgáltatásban használatosak, az Egyesült Államok katonai rendszereiben is jelen vannak, és például a németországi légi irányítás is OSS-alapokon nyugszik: ezek mind olyan területek, ahol csak a 120 százalékos biztonság elfogadható. 
Az Európai Uniónak immár saját licence is van: az Európai Unió nyilvános licence, melynek elsố verziója (az EUPL 1.0) 22 nyelven jelent meg, köztük magyarul is. Az $I D A$ - és $I D A B C$-programok keretében kifejlesztett eszközöket az európai intézményeken kívüli közigazgatási szervek az Európai Bizottság által adott licenc alapján használhatják, mivel az eszközök szerzói joga a bizottság által képviselt Európai Közösséget illeti meg. Egy ideje megnövekedett az érdeklődés a szoftverek forráskódjának olyan licenc alapján történố nyilvánosságra hozatala iránt, ami nem korlátozná a forráskód felhasználását és módosítását. Az eredeti EUPL-licencet - az IDABC célkitúzéseivel összhangban - ilyen szoftverekhez hozták létre. A licenc megszövegezése általános, így felhasználható származékos és egyéb alkotásokhoz, és használhatják más licencadók is. Ennek a licencnek az egyik elónye abban áll, hogy a közszféra szoftvereinek összességéhez létrehozott közös keret révén jogi értelemben is erósíti az interoperabilitást.

Önkormányzati szinten egy immár lezárult, nem spekuláción alapuló szoftveres „migrációt” érdemes példaként megemlíteni: Bristol város közigazgatásában 2005-ben indult meg az OSS-re való átállás, ami máig már 5500 asztali számítógépet érintett. A licencdíjakon a város 1,4 millió eurót takarított meg (a StarOffice programok telepítése 243 ezer euróba került, szemben az MS Office 1,8 millió eurós költségeivel). Maga az átállás azonban kétszer olyan költséges volt, mint egy sima upgrade esetében, a Microsoft termékválasztékán belül maradva: ennek oka a dolgozók betanítása az új szoftver alkalmazására, a dokumentumok konverziója és a segédanyagok elkészítése volt. Az átállás így összesen 632 ezer euróba került, tehát még így is sokkal olcsóbban sikerült a szoftverfrissítést megvalósítani, ráadásul a következó alkalommal ez az átállási költség már nem lesz ilyen jelentốs.

Az OSS terjedése az úgynevezett „migrációs” folyamatok révén zajlik, melyeknek az elósegítésére nagyszabású projektek indulnak szerte Európában, nemcsak a „gazdag” országokban, hanem a keleti térség államaiban is: többek között Szerbia, Horvátország és Bulgária is ebben látja a jövốt. Ezekben az országokban az OSS terjedése erôteljes politikai támogatást élvez, ennek célja a szoftverek legalizálása és a helyi szoftveripar fejlesztése.

A kutatás-fejlesztés terén a franciák végezték a legalaposabb elemzéseket. Szakembereik az alábbi három ajánlást fogalmazták meg:

1. Növelni kell a versenyt a „dobozos” szoftverek és a nyílt forráskódú szoftverek között új IT-projektek kiírásával. A verseny eredményeképpen 2012-re a közszférában alkalmazott szoftverek 20 százaléka várhatóan OSS lesz.

2. Adókedvezményekkel célszerú támogatni a nyílt forráskódú szoftverekkel foglalkozó cégeket (hasonlóan az Egyesült Államokhoz).

3. Franciaország szorgalmazza olyan nemzetközi szabványok kialakítását és bevezetését, amelyek elősegítik a „dobozos” és a nyílt forráskódú szoftverek átjárhatóságát.

Ha a nyílt forráskódú szoftverek piaca a várt mértékben növekszik, akkor a gazdasági elemzók szerint 36 százalékkal csökkenhetnek a cégek kutatási és fejlesztési költségei. Jelenleg az OSS-piac az adott szegmensnek csupán két százalékát teszi ki, de évente 40 százalékkal növekszik. A nyílt forráskódú szoftverek segítségével 131 ezer ember egyéves munkáját lehet megtakarítani, amelynek értéke eurómilliókra rúg. 
Az európai színtéren Franciaország és Nagy-Britannia mellett Spanyolország példáját érdemes kiemelni (lásd Extremadura-projekt), továbbá a legutóbbi idókben Hollandia és Dánia lépései érdemelnek különös figyelmet. Ez utóbbi országokban gyakorlatilag már kötelezố a nyílt szabványok használata. Számos fejlesztési projekt indult, a politika határozottan kiáll az OSS mellett: a kiadott irányelvek és stratégiák mellett kötelező erejú rendeletek és egyéb szabályozások mutatják a kormányok elkötelezettségét. Dániában a Ramboll Management for the Association of Open Source Providers elemzése szerint 550 millió dán korona (megközelítóleg 73,7 millió euró) megtakarítás érhetô el öt év alatt, ha a dán kormányszervek átállnak az ODF-formátum használatára. A hozzánk közelebb esó országok közül Románia, Bulgária, Horvátország és Szlovénia is stratégiai fontosságot tulajdonít az OSS bevezetésének.

Számos országban OSS-tudásközpontok, disszeminációs irodák és szervezetek alakultak. Ezek a szervezetek és projektjeik nemcsak a terjesztésben és a felmérésekben játszanak szerepet, hanem lobbitevékenységgel is hozzájárulnak a mozgalom erôsítéséhez. A disszeminációs projektek központjai számos esetben különböző egyetemek.

\section{Lehetséges akciók, beavatkozási területek}

A nyílt forráskódú szoftverek terjesztése nem kezelhetố egységes, egyetlen akcióval „megoldható” feladatként. Sokkal inkább számos területen egyidejúleg jelentkező horizontális lehetôségekról van szó. Az alábbiakban néhány kivitelezhetô akciót sorolunk fel.

- A fejlesztối szegmens támogatása: Az Egyesült Államok, több ázsiai állam vagy akár Románia gyakorlatához hasonlóan adókedvezményekkel és más juttatásokkal lehet támogatni a nyílt forráskódú szoftverekkel foglalkozó cégeket, vállalkozókat. Ha a szoftverfejlesztés hazai színtérre tevődik át, az a GDP mértékét befolyásoló piaci hatással jár (ez a felismerés tette politikai szlogenné és gazdasági akcióprogrammá az OSS támogatását Franciaországban).

- Utánpótlás: Magyarország nemzetközi szinten is kiemelkedóen magas színvonalú programozókat képez, a mérnökképzés jól kiforrott és nagy hagyományokra tekint vissza. A nyílt forráskódú szoftverek elốtérbe helyezése olyan OSS-programozói generációkat nevelhet ki, amelyek mind a hazai, mind a nemzetközi piacokon versenyképesek lehetnek. Ez a modell hatalmas jövedelemhez juttatta például Indiát a programozói tudás terén általános gyakorlattá vált outsourcing révén. Maga az Európai Unió is hatalmas igényekkel fellépő, meghódítható „piacot" jelent.

- Disszemináció: Az OSS terjesztésével növelhető a hazai lakosság legális szoftverhasználata, az így kialakuló piac elsôsorban a hazai fejlesztốk számára biztosít lehetôségeket. Ennek bevált eszközei a promóció, a felsố vezetối kiállás és a széles körú tájékoztatás.

- E-kormányzat: Az állami támogatással kifejlesztett szoftverek révén (lásd e-önkormányzat, kevés forrás, nagy elvárások) ingyenesen professzionális és inter-operábilis szoftverekkel lehet ellátni a közigazgatási szférát, megalapozva ezzel a 
back-office folyamatok összehangolását, és jelentôs költségcsökkenést lehet elérni. Megszúnnek az egyedi fejlesztések, a pluszköltségek, és ráadásul az állampolgári jogok is jobban érvényesülnek, arról nem is beszélve, hogy a kormányzat valóban a saját kezében tarthatja az „érzékeny” információkkal kapcsolatos és más kritikus fontosságú múveletek biztonságos végrehajtását lehetôvé tevố szoftvereket.

\section{Oktatás}

Az oktatás hagyományosan az OSS egyik reprezentatív területe. A költségvetés, az oktatási módszerek és a piacképes munkaerô képzése tekintetében egyaránt kikerülhetetlen fontosságú az OSS. A Datamonitor kutatócég prognózisa szerint az OSS piaca 2012-re az oktatási szférában el fogja érni a 489 millió dolláros forgalmat. A nyílt forráskódú szoftverek használatával a brit kormány évente több mint 800 millió eurót takaríthat meg - állítja George Osborne brit konzervatív politikus. Ebból a pénzból akár húszezer új tanár fizetését lehetne biztosítani.

Az oktatás terén Oroszország kínálja a legjobb példát: 2009-ig minden iskolába GNU/Linux operációs rendszereket telepítenek. A teljes migrációra és fejlesztésre három évet szánnak; a kísérleti projektek már megindultak. Egy ekkora országban gigantikus megtakarítások érhetók el már rövid távon is csupán a licencdíjakon, a hosszú távú gazdasági hatásokról nem is beszélve. Hasonló projekteket indítottak Japánban és Dél-Koreában is.

A megtakarítások nemcsak a licencdíjakban jelentkeznek, hanem abban is, hogy a kormányzati szféra megszabadulhat a monopolhelyzetben levố szoftverfejlesztókkel kötött szerződések jelentette, hosszú ideig fennálló kényszerhelyzetektól. A nyílt forráskódú szoftverekkel hatékonyabb és jobb e-kormányzatot lehet kiépíteni. A brit szakemberek példaképpen Spanyolországot, Németországot és Hollandiát emelik ki: ezekben az országokban az utóbbi idóben nagyságrendekkel növekszik az OSS használata. Osborne egy másik elemzésre is felhívja a figyelmet, mely szerint a brit iskolák a nyílt forráskódú szoftverek használata révén 50 százalékkal csökkenthetik IT-költségei- ket. Az oktatási szféra, fóként az iskolák számára a költségmegtakarítás a legfontosabb. Az iskolák szakemberei szerint kell számítani problémákra az átállás során a diákok részéról, de ezek némi képzéssel és gyakorlással megoldhatók, a megtakarítás viszont igen jelentôs lehet.

A horvát kormány egy példaértékú projekt keretében négy kézikönyvet oszt ki minden tanárnak és állami alkalmazottnak: a négy kötet mindegyike egy-egy OpenOffice alkalmazással foglalkozik, ismertetve a Writer, Calc., Impress és Base rendszereket. A kézikönyvektól a szabad szoftverek népszerúsítését és a velük kapcsolatos ismeretek terjedését várják.

A törökországi általános iskolákban szintén nagy hangsúlyt helyeznek nemcsak a szoftverre, hanem az alkalmazásához szükséges készségek oktatására is. A szoftverekkel külön tantárgy keretében fog megismerkedni minden 11-12 év körüli tanuló. A jövóben minden török iskolai számítógép üzembe helyezésekor lehet majd választani, hogy az Linux vagy Microsoft operációs rendszerrel múködjön-e. Nem véletlen, hogy Nagy-Britannia mellett Törökországban indult meg az egyik legnagyobb e-önkormányzati OSS-fejlesztési akció, a Yerelnet-program. 


\section{Olvasnivalók}

A témában egyelőre viszonylag kevés megbízható adat, elemzés lelhető fel. Ezeknek a száma az utóbbi idóben egyre nó, és hamarosan ugrásszerú növekedés várható ezen a téren, mivel a piacelemzố cégek ezt a szegmenst is bevonták a vizsgálandó területek közé. Íme néhány jelenleg is elérhető hasznos forrás, szakanyag.

Unlikely bedfellows: open source initiatives and commercial vendors in the education market. http://www.datamonitor.com/industries/research/?pid=DMTC2150\&type=Report

Berlini szoftvermigrációs sorvezetô, alapfogalmakkal, alapkérdésekkel. http://www.kbst.bund.de/cln_012/nn_836802/SharedDocs/Anlagen-kbst/ Migrationsleitfaden/migration-guide-2nd-edition_pdf,templateId=raw,property= publicationFile.pdf/migration-guide-2nd-edition_pdf.pdf

Az Európai Bizottság OSS stratégiájáról. http://ec.europa.eu/idabc/en/document/7389/5998

A francia gazdasági stratégia, benne az OSS ajánlásával. http://lesrapports.ladocumentationfrancaise.fr/BRP/084000041/0000.pdf

Holland szakanyag a nyílt szabványok használatáról a közigazgatásban: Guide on How to Use Mandatory Open Standards for Software in the Public Sector. http://ec.europa.eu/idabc/servlets/Doc?id=29887

Egy kiváló sorvezető a franciáktól: 23 kérdés, 23 válasz egyszerúen megfogalmazva a közigazgatás résztvevőii számára. http://www.synergies-publiques.fr/IMG/pdf/FAQ-LL-V1.2.0.pdf

A horvát OSS ajánlás. Angolul: http://www.ehrvatska.hr/sdu/en/Dokumenti/StrategijeIProgrami/categoryParagraph/04/ document/Open_Source_Software_Policy.pdf

Brit forrás két hasznos dokumentummal és felméréssel: http://www.ogc.gov.uk/7023_4187.asp

Study on the effect on the development of the information society of European public bodies making their own software available as open source http://www.publicsectoross.info/images/resources/15_154_file.pdf

OSS-oktatás: EU SELF projekt. http://selfproject.eu/

A francia minisztérium felmérése az OSS gazdasági hatásairól (is). Franciául: http://www.minefi.gouv.fr/directions_services/sircom/technologies_info/immateriel/ immateriel.pdf

Study on the economic impact of open source software on innovation and the competitiveness of the Information and Communication Technologies (ICT) sector in the EU. http://ec.europa.eu/enterprise/ict/policy/doc/2006-11-20-flossimpact.pdf

TOSSAD jelentések. http://www.tossad.org/publications/highlights

COSPA eredmények. http://www.cospa-project.org/workplan.html 